症例

上部消化管出血を合併した仮性膵囊胞胃穿通に対して 胃全摘術を施行した 1 例

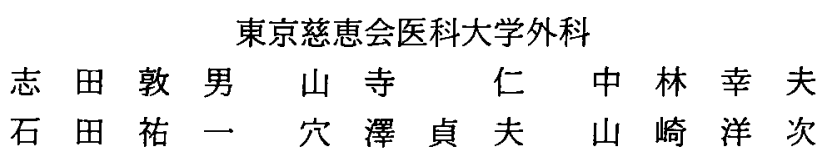

症例は 48 歳, 男性. 平成11年 1 月より咳濑, 発熱が出現し次第に呼吸困難も出現し, 2 月 17 日に当院へ紹介され入院した. 来院時胸部単純X線写真で左胸水を認め, 腹部 CT で直径 $6 \mathrm{~cm}$ 大の仮性膵囊胞を認めた. 血液生化学的検查で, 慢性膵炎急性增悪と診断し 保存的に治療していたところ，第20病日に突然吐血し，胃内視鏡下止血術を試みたもの の止血できず緊急開腹手術を施行した。術中に仮性膵谼胞の胃穿通を確認し, 胃全摘術 を施行した。

慢性膵炎に合併した仮性膵襄胞の報告は多いが上部消化管大量出血に至る胃穿通を生 じた報告は少ない。

索引用語：仮性膵蘘胞, 消化管穿通, 慢性膵炎

はじめに

近年の各種画像検査の技術の進歩と普及により様及 な大きさ，種類の膵暴胞性病変が指摘されるようにな $\eta$, 外科的に切除の対象となる症例も増加してきた。

しかし，一方で臨床症状を伴わない場合や悪性の可 能性を否定できない場合など, 治療法の選択に迷うこ とも稀ではない. 本報告例は, 数年前より他院にて仮 性脺亳胞の存在を指摘されていたが, 放置していたと ころ, 慢性膵炎急性增悪を契機に仮性膵襄胞が胃穿通 を生じ，吐血のコントロール目的で胃全摘術を余儀な くされた稀な例であるので報告する.

$$
\text { 症例 }
$$

症例：48歳, 男性.

主訴：咳嗽。

家族歴：特記事項なし。

既往歴: 高血圧, 高尿酸血症, 左膿胸. 平成 5 年他 院で保存的治療 (不詳).

飲酒歴：大量習慣飲酒者.

喫煙歴：一日40本（20歳～).

現病歴：平成11年 1月より咳嫩, 発熱が出現した.

2001 年 5 月 1 日受付 2001 年 9 月 5 日採用

〈所属施設住所〉

干105-8461 東京都港区西新橋 3-25-8
平成11年 2 月 17 日呼吸困難が出現し, 他院を受診。胸 部レントゲン上左胸水を指摘され，当院を受診し，同 日緊急入院した。

入院時現症：身長 $173 \mathrm{~cm}$, 体重 $58 \mathrm{~kg}$. 体温 $37.4^{\circ} \mathrm{C}$. 血圧143/99. 意識レベル清明, 結膜に黄疸貧血を認め ず．腹部は平坦軟で肝脾を触知しなかった．全身の表 在リンパ節を触知しなかった. 胸部は左呼吸音の低下 を認めた。

入院時検查成績：血液検查では白血球と CRP が高 值の他, CEA が軽度上昇していた. 胸水生化学検査で はアミラーゼ, リパーゼが高值であり, 培養は陰性で あることから胸水の原因は膵性胸水と考えられた（表 1).

胸部 $\mathbf{X}$ 線所見：左胸腔内は，ほとんど胸水で満たさ れており，左心陰影は追えないためCTRは不明であ った．右胸腔内に胸水は認められなかった（図 1 ).

腹部 CT 検查所見：薄い壁を有する襄胞が脺体部か ら一部は小網を経て食道裂孔へ，一部は膵尾部から腹 腔内, 横行結腸間膜, 結腸周囲へ進展していた。膵実 質は脺鉤部と体部の一部を除き融解し，その周囲に液 体貯留を認めた（図 2 ）。

入院後経過：入院時左胸腔内に胸腔ドレーンを㨂入 した. 1 日約 1 リットルの胸水の排出が 5 日間持続し た.その後胸水の排出が止まったため第 13 病日ドレー 
表 1 入院時検査成績

\begin{tabular}{|c|c|c|c|c|c|}
\hline 血算 & & AMY & $276 \mathrm{IU} / \mathrm{L}$ & T.P & $4.4 \mathrm{~g} / \mathrm{dl}$ \\
\hline WBC & $11,370 / \mu 1$ & $\mathrm{Na}$ & $141 \mathrm{mmol} / 1$ & Alb & $2.4 \mathrm{~g} / \mathrm{dl}$ \\
\hline $\mathrm{RBC}$ & $4,45 \times 10^{6} \mu 1$ & $\mathrm{~K}$ & $4.0 \mathrm{mmol} / 1$ & $\mathrm{LDH}$ & 197IU/L \\
\hline $\mathrm{Hb}$ & $13.8 \mathrm{~g} / \mathrm{dl}$ & $\mathrm{Cl}$ & $106 \mathrm{mmol} / 1$ & SCC & $8.4 \mathrm{ng} / \mathrm{ml}$ \\
\hline \multirow[t]{2}{*}{ Plt } & $589 \times 10^{3} \mu 1$ & $\mathrm{CRP}$ & $16.2 \mathrm{mg} / \mathrm{dl}$ & ProGRP & $5.0 \mathrm{pg} / \mathrm{ml}$ \\
\hline & & & & $\mathrm{ADA}$ & $33.5 \mathrm{IU} / 1$ \\
\hline 血液生化学 & & $\mathrm{CEA}$ & $6.0 \mathrm{ng} / \mathrm{ml}$ & CEA & $4.4 \mathrm{ng} / \mathrm{ml}$ \\
\hline T.Bil & $0.5 \mathrm{mg} / \mathrm{dl}$ & CA19-9 & $7.5 \mathrm{U} / \mathrm{ml}$ & シフラ & $36 \mathrm{ng} / \mathrm{ml}$ \\
\hline D.Bil & $0.2 \mathrm{mg} / \mathrm{dl}$ & $\mathrm{SCC}$ & $0.5 \mathrm{ng} / \mathrm{ml}$ & ヒアルロン酸 & $7,800 \mathrm{ng} / \mathrm{ml}$ \\
\hline GOT & $13 \mathrm{IU} / \mathrm{L}$ & NSE & $13 \mathrm{ng} / \mathrm{ml}$ & リソチーム & $7.3 \mu \mathrm{g} / \mathrm{ml}$ \\
\hline GPT & $10 \mathrm{IU} / \mathrm{L}$ & $\mathrm{HbA}_{1 \mathrm{c}}$ & $4.50 \%$ & リバルタ反応 & $(-)$ \\
\hline T.P & $6.7 \mathrm{~g} / \mathrm{dl}$ & & & 比重 & 1.027 \\
\hline Alb & $3.5 \mathrm{~g} / \mathrm{dl}$ & 胸水生化学 & & 培善 & $(-)$ \\
\hline UN & $11 \mathrm{mg} / \mathrm{dl}$ & AMY & $895 \mathrm{IU} / \mathrm{L}$ & 外観 & 茶褐色混濁 \\
\hline $\mathrm{Cr}$ & $0.7 \mathrm{mg} / \mathrm{dl}$ & Lipase & $295 \mathrm{IU} / \mathrm{L}$ & & \\
\hline
\end{tabular}

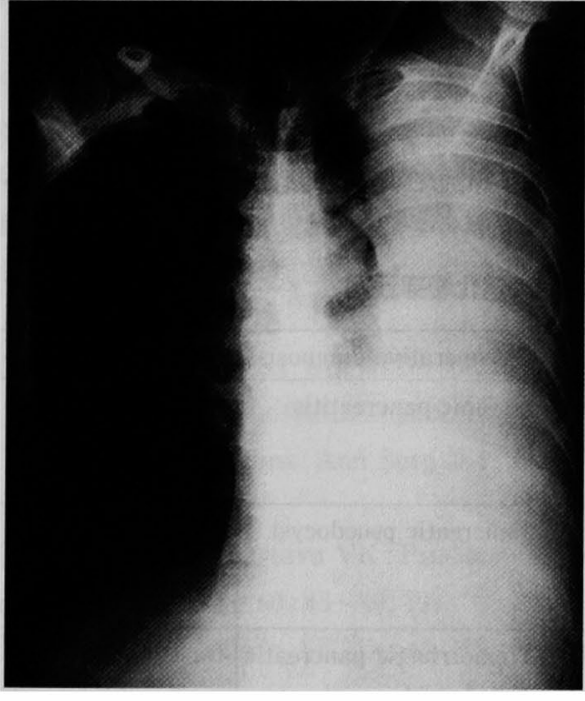

図 1 胸部単純レントゲン写真: 左胸腔は胸水 で満たされている.

ンを抜去した。血液, 胸水, 腹部 CT 検査により, 胸 水の原因は仮性膵囊胞, 慢性膵炎による, 反応性胸水 と考え, 慢性萃炎急性増悪に対する治療を開始した。 ところが第14病日高熱が出現し，第20病日吐血したた め緊急胃内視鏡にて止血を試みたが，困難であったた め第21病日緊急開腹手術を施行した。術前診断は, Mallory-Weiss 症候群であった。

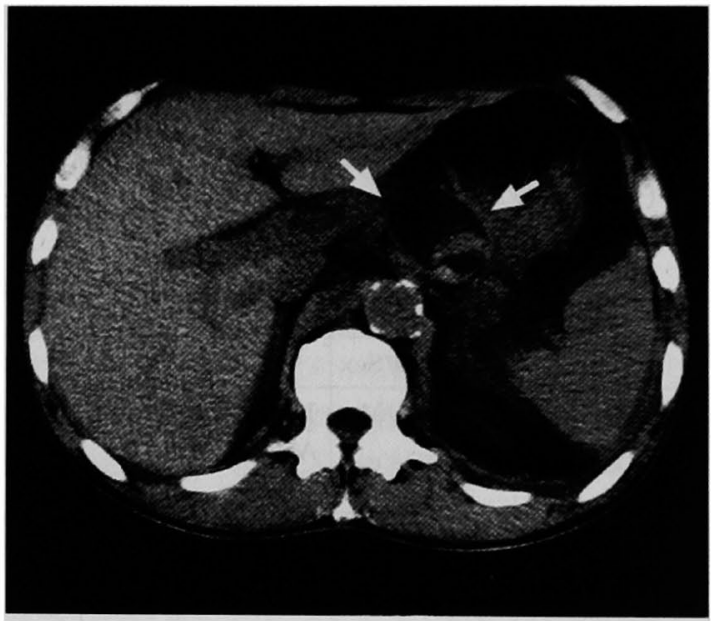

図 2 腹部 CT : 膵体尾部に直径 $6 \mathrm{~cm}$ 大の囊胞 (矢印) を 認める.

手術：胃全摘術および仮性膵娈胞外㾞造設術を施行 した. 胃前壁を切開すると胃内は凝血塊で満たされて おり, 胃体上部後壁に仮性膵囊胞との交通を認めた。 膵前面と胃小彎および胃後壁は膵炎によると思われる 癒着が著しかった，胃の内腔から観察したところ壊胞 内部に動脈性の出血を認め出血源と考えた。同部位を 止血後, 胃全摘 Roux-Y 再建術を施行した. 切開した 霊胞内に $10 \mathrm{Fr}$ バルーンカテーテルを留置し外瘻を造 設した．出血量は $5,020 \mathrm{ml}$ であった. 
切除標本所見：胃体上部後壁に直径約 $3 \mathrm{~cm}$ の穿通 部を認める。この個所と仮性膵囊胞が交通していた(図 3 ).

術後経過：術後14日目外瘦チューブを抜去し, 術後 28日目退院した。その後食道一小腸吻合部に膜状狭窄 を生じ，内視鏡的拡張術を施行した。平成 13 年 7 月 20 日現在経過は良好である。

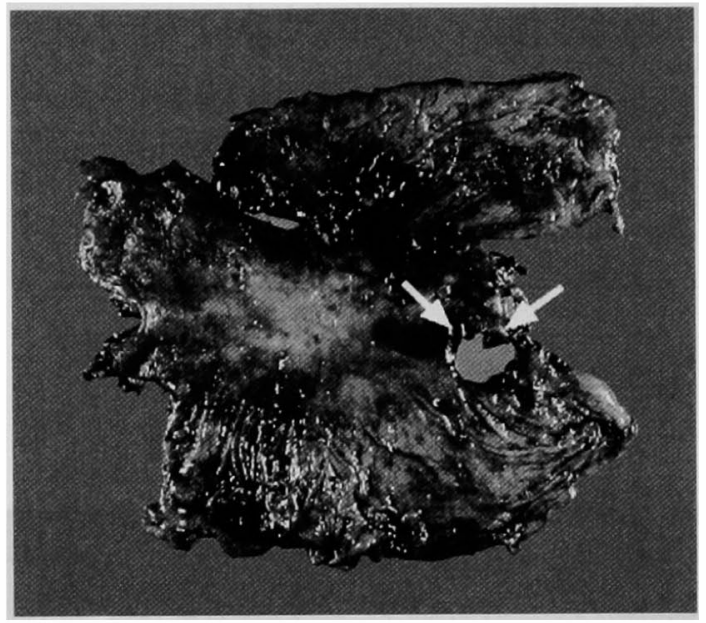

図 3 胃切除標本：胃体上部後壁に直径 $3 \mathrm{~cm}$ の穿通部 （矢印）を認める.
考 察

慢性萃炎には約 $10 \sim 15 \%$ に仮性膵蛮胞が合併すると いわれているが, その約 $30 \% に$ 膿瘍形成, 穿孔, 出血 （消化管出血, 腹腔内出血, 襄胞内出血）などの合併

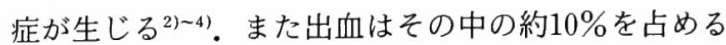
が重篤であり, 死亡率は $25 〜 40 \%$ と仮性膵囊胞の合併 症中最も高いと報告されている ${ }^{3)}$. 囊胞内出血の発生 機序としては, (1)消化液の襄胞内逆流により活性化さ れた膵酵素が, 囊胞内微小血管壁を自己融解し, 壁か らの出血をひきおこす。（2)囊胞内圧の上昇による. (3) 膵の炎症が隣接動静脈に波及し仮性動静脈瘤を形成 し，それが襄胞内に破綻する，といった機序が考えら れている ${ }^{9)}$.また, 出血後の経過としては, (1)偽動静脈 瘤のまま残存する. (2)消化管に直接穿破し消化管出血 を起こす. (3)膵管や胆道に穿破しVater 乳頭を介して 消化管出血を起こす. (4)腹腔内破裂，などが考えられ $3^{(0)}$. 本症例は術中診断で, 仮性膵毞胞の胃体上部後壁 への直接穿通を認めたため, (2)に相当する.

われわれが検索した限り，1972年以降本邦にて仮性 膵襄胞が消化管穿通を起こした報告は本症例を含め て，8例あるが，1例を除きいずれも胃に穿通してい $3^{778) 121 \sim 17)}$. そのうち術前に消化管出血の原因が仮性 脺囊胞の胃穿通であると診断できた報告はない（表

表 21972 年以降報告された仮性膵囊胞の消化管穿通例

\begin{tabular}{|c|c|c|c|c|c|c|c|}
\hline Author & year & Age/Sex & Symptom & S-Amy & Fenetration & Preoperative diagnosis & Treatment \\
\hline 1) H.Saitou & 1972 & $35 / \mathrm{M}$ & $\begin{array}{l}\text { Jaundice } \\
\text { Abd pain }\end{array}$ & ? & $\begin{array}{c}\text { CBD, } \\
\text { Duodenum }\end{array}$ & Chronic pancreatitis & $\begin{array}{l}\text { Pancreatectomy } \\
\text { splenectomy } \\
\text { transversectomy }\end{array}$ \\
\hline 2) Y.Masuda & 1975 & $41 / \mathrm{M}$ & $\begin{array}{l}\text { Nausea } \\
\text { Hematemesis }\end{array}$ & $219 \mathrm{U} / 1$ & Stomach & Pancreatic psuedocyst & $\begin{array}{l}\text { Totalgastrectomy } \\
\text { Splenectomy } \\
\text { Distal pancreatectomy }\end{array}$ \\
\hline 3) K.Iwamura & 1980 & $36 / \mathrm{M}$ & $\begin{array}{l}\text { Abd pain } \\
\text { Hematemesis }\end{array}$ & $520 \mathrm{SR} / \mathrm{dl}$ & Stomach & $\begin{array}{l}\text { Hemorrhagic pancreatic } \\
\text { psuedocyst }\end{array}$ & Gastrocystostomy \\
\hline 4) M.Takami & 1981 & $38 / \mathrm{M}$ & $\begin{array}{l}\text { Severe anemia } \\
\text { Easy fatigability }\end{array}$ & $50 \mathrm{U} / 1$ & Stomach & Pancreatic cancer & $\begin{array}{l}\text { Totalgastrectomy } \\
\text { Splenectomy } \\
\text { Distal pancreatectomy }\end{array}$ \\
\hline 5) M.Tanigawa & 1992 & $61 / \mathrm{M}$ & $\begin{array}{l}\text { Left abd pain } \\
\text { Abd pain }\end{array}$ & $614 \mathrm{U} / 1$ & Stomach & Pancreatic psuedocyst & Conservative treatment \\
\hline 6) K.Okamura & 1996 & $66 / \mathrm{M}$ & $\begin{array}{l}\text { Right epigastric } \\
\text { pain Hematemesis }\end{array}$ & $83 \mathrm{U} / 1$ & Stomach & Residual gastric ulcer & $\begin{array}{l}\text { Totalgastrectomy } \\
\text { Splenectomy }\end{array}$ \\
\hline 7) K.Ishihara & 1998 & $34 / \mathrm{M}$ & $\begin{array}{l}\text { Left epigastric pain } \\
\text { Hematemesis }\end{array}$ & $76 \mathrm{U} / 1$ & Stomach & Splenic psuedoaneurysm & $\begin{array}{l}\text { Distal pancreatectomy } \\
\text { Splenectomy } \\
\text { Partial gastrectomy }\end{array}$ \\
\hline 8) A.Shida & 1999 & $48 / \mathrm{M}$ & Cough & $276 \mathrm{U} / 1$ & Stomach & Mallory-Weiss Synd. & Total gastrectomy \\
\hline
\end{tabular}


$2)^{7(8) 121-177 .}$ 石原ら ${ }^{8)}$ は吐血を数回におよふ内視鏡的 止血術で止血した後, カラードップラーUS, ダイナミ ック CT, 脾動脈造影検查を行い脾仮性動脈瘤の胃穿 破と診断したが, 術前確定診断にはいたらなかったと 報告している。しかしカラードップラーUS, ダイナミ ックCTによって襄胞内の血流状態を経時的に観察す ることで，仮性膵哓胞内出血の場合には致死的出血以 前の早期診断がより可能になると述べている.

大量吐血には椂々な原因があるが，画像診断で膵哓 胞が認められた場合, 異胞の胃穿通を念頭において, 治療に取り組むべきである．また治療の原則は破綻し た血管を含めた咅胞の摘出が理想的である．本症例で は胃全摘出を施行したがこれは過大手術であったとい わざるをえない. 部分切除で治空できる可能性は十分 あったものと思われる．また全身状態不良や綝り返す 炎症による䈍着で糞胞の完全摘出の困難が予想される 症例では超選択的動脈造影による塞栓術が有効であっ たとする報告も散見され，個々の症例に応じた治療法 を選択する必要があろう ${ }^{18)}$.

\section{結 語}

慢性膵炎に合併した仮性膵譱胞が膵性胸水を引き起 こし,さらに胃への直接穿通した稀な1症例を経験し たので, 若干の文献的考察を加えて報告した.

本論文の要旨は第61回日本臨床外科学会総会（1999年11 月25日, 東京)に扔いて発表した。

\section{文 献}

1) Cameron JL, Kieffer RS, Anderson WJ, et al : Internal pancreatic fistulas: pancreatic ascites and pleural effusions : Ann Surg 184 : $587-593$, 1976

2) Simpsom A, Srivastava VK : Psudocyst of pancreas. Br J Surg $60: 45-49,1973$

3) Stabile BE, Wilson SE, Debas HT:Reduced mortality from bleeding pseudocyst and pseudoaneurysm caused by pancreatitis. Arch Surg 118: 45-49, 1973

4) Sankaran $\mathrm{S}$, Walt $\mathrm{AJ}$ : The natural and unnatural history of pancreatic pseudocysts. Surgery $62: 37-44,1975$

5）小林利彦, 木村泰三, 吉田雅行他：膵性胸水を伴 い, CT にて胸腔内との交通が疑われた仮性膵衰
胞の 1 例. 胆と膵 $16: 615-619,1995$

6）山本宏明, 雄谷義太郎, 佐藤有三他：脾臟に穿破 した仮性脺震胞の 1 例.胆と膵 $15: 1163-1168$, 1994

7）高濱 誠, 屋良敏男, 与那龩修他：消化管出血及 び腹腔内出血を伴った仮性脺蓄胞の 1 手術例. 日 臨外会誌 $56 ： 1667-1670,1995$

8）石原寛治, 山田 正, 鈴木範男他：胃穿通をきた した仮性膵謱胞内出血の 1 例. 日消外会誌 32 ： $870-874,1999$

9）佐藤和宏，今野哲朗，佐野文男他：仮性膵㲤胞内 出血の 1 治験例. 臨外 $39: 1621-1624,1984$

10）山野三紀，並木正義他：脾動脈溜の偽性動脈瘤穿 刺による膵仮性咅胞内出血の 1 例. Gastroenterol Endosc 30:1255-1268, 1988

11）佐藤 力, 遠藤 剛, 土屋豊一他：十二指腸乳頭 部より上部消化管出血を来した偽性動脈瘤を伴う 仮性膵萋胞内出血の 1 例. 胆と脺 $6: 1421-$ 1426, 1985

12）斉藤 光, 細井敬三, 園田仁志他: 膵頭部仮性脺

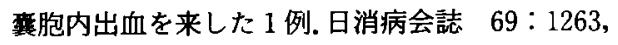
1972

13）増田幸久, 竹腰隆男, 丸山雅一他：吐血, 下血を きたした慢性反復性膀炎の 1 例. Prog Dig Endoscopic $7: 88-91,1975$

14）岩村健一郎, 板倉 勝, 松崎松平他：脾動脈閉塞 をともない胃に穿孔した脺仮性膵荛胞の 1 例。日 消病会誌 $77 ： 1293-1297,1980$

15）高見元敕, 花田正人，木村正治他：仮性胼裹胞内 に出血し，吐血を生じた慢性脺炎の 1 例。胃と腸 $16: 1355-1362,1981$

16）谷川 誠, 中野 哲, 武田 功他：大出血を呈し 保存的治療で改善した脺襄胞の 1 例. 日内会誌 $81: 103-104,1992$

17）岡村啓二, 守田信義，折田雅彦他：残胃に穿破し た膵仮性蕫胞内出血の 1 例。脺葴 $11: 393-397$, 1996

18）堀口裙司, 森田 稞, 丁子 清他: 脾動脈塞栓術 により救命し得た hemosuccus pancreatics $の 1$ 例. 臨放線 32：1173-1176, 1987 


\title{
TOTAL GASTRECTOMY FOR GASTRIC PENETRATION OF PSEUDOCYST OF PANCREAS WITH UPPER GASTROINTESTINAL BLEEDING-REPORT OF A CASE-
}

\author{
Atsuo SHIDA, Hitoshi YAMADERA, Yukio NAKABAYASHI, \\ Yuuichi ISHIDA, Sadao ANAZAWA and Yoji YAMAZAKI \\ Department of Surgery, The Jikei University School of Medicine
}

A 48-year-old man was referred to the hospital on February 17 1999, because cough and fever started in January and then dyspnea gradually developed. On Admission, a plain chest $\mathbf{x}$-ray film revealed left pleural effusion and an abdominal CT scan visualized a pseudocyst of pancreas $6 \mathrm{~cm}$ in diameter. With a blood biochemical study, chronic pancreatitis in an acute phase was diagnosed and conservative treatment was started. On the 20th hospital day, however, hematemesis suddenly occurred and an attempt of gastric endoscopic hemostasis was unsuccessful. An emergency operation was performed. During the operation, gastric penetration of the pseudocyst of pancreas was confirmed, and a total gastrectomy was made.

Although many cases of pseudocyst of pancreas associated with chronic pancreatitis have been reported, such cases as gastric penetration of pancreatic pseudocyst has caused massive upper gastrointestinal bleeding are rare. 